\title{
The Lying-In Asylum in Mannheim (Germany) and Its Resident Physicians
}

\author{
Georg A. Petroianu1 ${ }^{*}$, Anka Stegmeier-Petroianu² \\ ${ }^{1}$ Herbert Wertheim College of Medicine, Florida International University, Miami, FL, USA \\ ${ }^{2}$ Medical Faculty Mannheim, Heidelberg University, Mannheim Institute of Public Health, Social and Preventive Medicine, \\ Mannheim, Germany \\ Email: *georg.petroianu@fiu.edu
}

How to cite this paper: Petroianu, G. A., \& Stegmeier-Petroianu, A. (2018). The Lying-In Asylum in Mannheim (Germany) and Its Resident Physicians. Advances in Historical Studies, 7, 147-161. https://doi.org/10.4236/ahs.2018.73010

\section{Received: July 17, 2018}

Accepted: September 15, 2018

Published: September 18, 2018

Copyright (c) 2018 by authors and Scientific Research Publishing Inc. This work is licensed under the Creative Commons Attribution International License (CC BY 4.0).

http://creativecommons.org/licenses/by/4.0/

\begin{abstract}
Alfons Mermann is best known for establishing the Luisenheim Woechnerinnenasyl (lying-in asylum) at the end of the $19^{\text {th }}$ century in Mannheim, Baden. The Luisenheim, owing its namesake to the Grand Duchess Luise of Baden (1838-1923), was a significant step forward in the provision of a safe delivery environment for married women of modest means. Mermann used his position as the Luisenheim's director to promote both the training of midwives and of obstetricians. This short work explores the lives and families of the physicians associated with the Luisenheim from its inception to the first years under Mermann's successor, Karl Preller.
\end{abstract}

\section{Keywords}

Mermann, Alphons, Preller, Karl, Luisenheim, Lying-In Asylum in Mannheim

\section{Introduction}

During the $19^{\text {th }}$ century, as a response to the desperate situation of the urban poor, Woechnerinnenasyle (lying-in asylums) were established in many German cities. The first one to open in 1830 was the Mariannen-Institut in Aachen (Aix-la-Chapelle), result of the efforts of a Prussian military physician Dr. Vitus Jacob Metz (1792-1866) and of the generosity and engagement of the female local population. How revolutionary and way ahead of its time the Mariannen-Institut really was (named after HRH Princess Marianne of Prussia [1785-1846]) can only be understood considering that it took over half a century until a similar institution opened in Duesseldorf in 1882 under the leadership of Dr. Anton Hucklenbroich (1846-1907) (Hucklenbroich, 1898; Metz, 1838). The Luisenheim in Mannheim (Baden), owing its namesake to HRH the Grand Du- 
chess Luise of Baden (1838-1923), the third lying-in asylum in a German state (Baden), was established 1887 to provide a safe delivery environment for married women of modest means. The Mannheim asylum was the result of the effort of Dr. Alfons Mermann (1852-1908) and the support of the local establishment (Mermann, 1903). While not being the first one to be opened, the Mannheim institution was however not only the largest but by far the best known and served as a model for many more to come (Schmitz-Cliever, 1966). Only one year later, the asylums in Magdeburg (Dr. Johannes Brennecke [1849-1931]) and then Cologne (1889), Elberfeld and Bremen (1890) opened, followed in the subsequent years by a significant increase both in the number of new institutions and of available beds. The shared belief in the turn of the century Germany was, as stated by Brennecke, that establishing gynecological departments at all public hospitals and offering lying-in asylums for married women, separated and isolated from the hospital routine, as centers of hygiene for the whole delivery and lying-in process, were the two demands that when fulfilled would make a healthy development of the female health in the near future likely (Gynaekologische Abtheilungen an allen staedtischen Krankenhauesern und gesonderte, vom Betriebe des Krankenhauses losgeloeste ... Woechnerinnen-Asyle fuer Ehefrauen als Centren der gesammten Geburts- und Wochenbett-Hygiene das sind in $\mathrm{Ku}$ erze die beiden Forderungen, von deren Erfuellung in naechster Zukunft eine gesunde Fortentwicklung der Frauenpflege wird erwartet werden duerfen!) (Brennecke, 1899).

\section{The Luisenheim in Mannheim (Baden)}

The Mannheim asylum was the result of the effort of Dr. Alfons Mermann (1852-1908). The institution was first located in M3,5 and had a capacity of 12 beds (Mannheim's city center is laid out in a grid pattern; each quadrant is designated by a letter and a number (M3); the second number (5) indicates a particular building within the quadrant). With the support of the city's lord mayor Oberbuergermeister Otto Beck (1846-1908) and his associate mayor Eduard von Hollander (1852-1935) the asylum moved in 1903 to a much larger dedicated building in C7,4 (26 beds). The new site was very modern at the cutting edge of technology, equipped with electricity, central heating, hot and cold running water, telephone, elevators and state-of-the-art medical equipment and sterilization facilities. The institution was directed by Dr. Mermann as chief-physician [Dirigierender Arzt] and run with the help of the second physician (Dr. Paul von Hollander [1865-1937]) and of a stream of residents [Assistenzaerzte] and volunteering physicians.

The institution proved to be enormously successful. While in the first year of its existence some 47 women were admitted, fifteen years later the number of admittances was already at 929 (Eckert, 1906). The Luisenheim was also a site of scholarly activity where therapeutic approaches were constantly reviewed and results published, not only by Mermann (Mermann, 1880, 1883, 1884, 1887), but 
also by his staff, associates and volunteers: Drs. Emilie Louise Frey, the first woman to study medicine and receive a Doctoral Degree from the University of Basel (Frey, 1897), Eugen Peiser (Peiser, 1898; Peiser, 1899a, 1899b), Felix Heymann (Heyman, 1899), Karl Schumacher (Schumacher, 1901), Georg Zander (Zander, 1901, 1902) and Georg van der Briele (Van Der Briele, 1903) as listed in the 1903 Festschrift [celebration publication], and Max Jacoby [Jacoby, 1904 \& 1905], Rudolf Katz (Katz, 1905), Alfred Eckert (Eckert, 1906), Walther Bender and Karl Preller thereafter (Preller, 1907a). It was Preller who succeeded Mermann as Director of the Luisenheim after Mermann's early death in 1908 and also the one who authored Mermann's obituary (Preller, 1908).

Alphons Mermann (1852-1908) (Figure 1) the chief-physician [Dirigierender Arzt] at the Luisenheim was the was the son of Dr. Samuel Meermann (1817-1888) a General Practioner (Praktischer Arzt) in Mannheim and Regina Rosenthal (1829-1897). A more detailed biography of Mermann was recently published (Miller \& Petroianu, 2018).

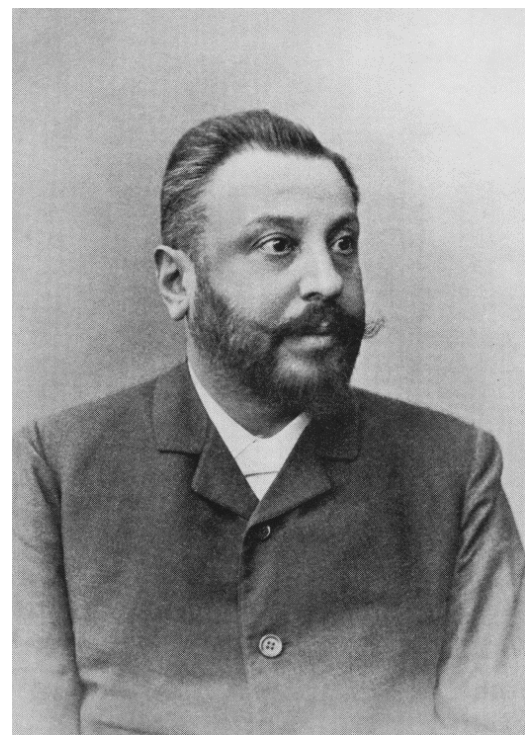

Figure 1. Alphons Mermann (1852-1908), the chief-physician [Dirigierender Arzt] at the Luisenheim; Photo kindly provided by Stadt-archiv Mannheim-Institut für Stadtgeschichte; Dr. Anja Gillen.

Albert Paul von Hollander (1865-1937) the second-in-command at the Luisenheim was born in Riga, studied first history in Dorpat and then medicine in Dorpat and Koenigsberg in Preussen (now Kaliningrad). His 1894 Doctoral dissertation was titled $A$ Contribution to the Anatomy of the Human Parietal Bone (Ein Beitrag zur Anatomie des Scheitelbeines des Menschen) (Figure 2). He married 1908 the daughter of lawyer Albrecht Hinderer from Konstanz. His curriculum vitae as included in the Doctoral dissertation do not provide details regarding his parents (so the exact relationship with Eduard von Hollander [the associate Mayor of Mannheim] could not be established by the authors). He must have been however a close relative since he lived at the same address in 
Mannheim as Marie Magdalene von Hollander born Carus, the mayor's mother-in-law (Tulla street 10). Paul died 1937 in Mannheim.
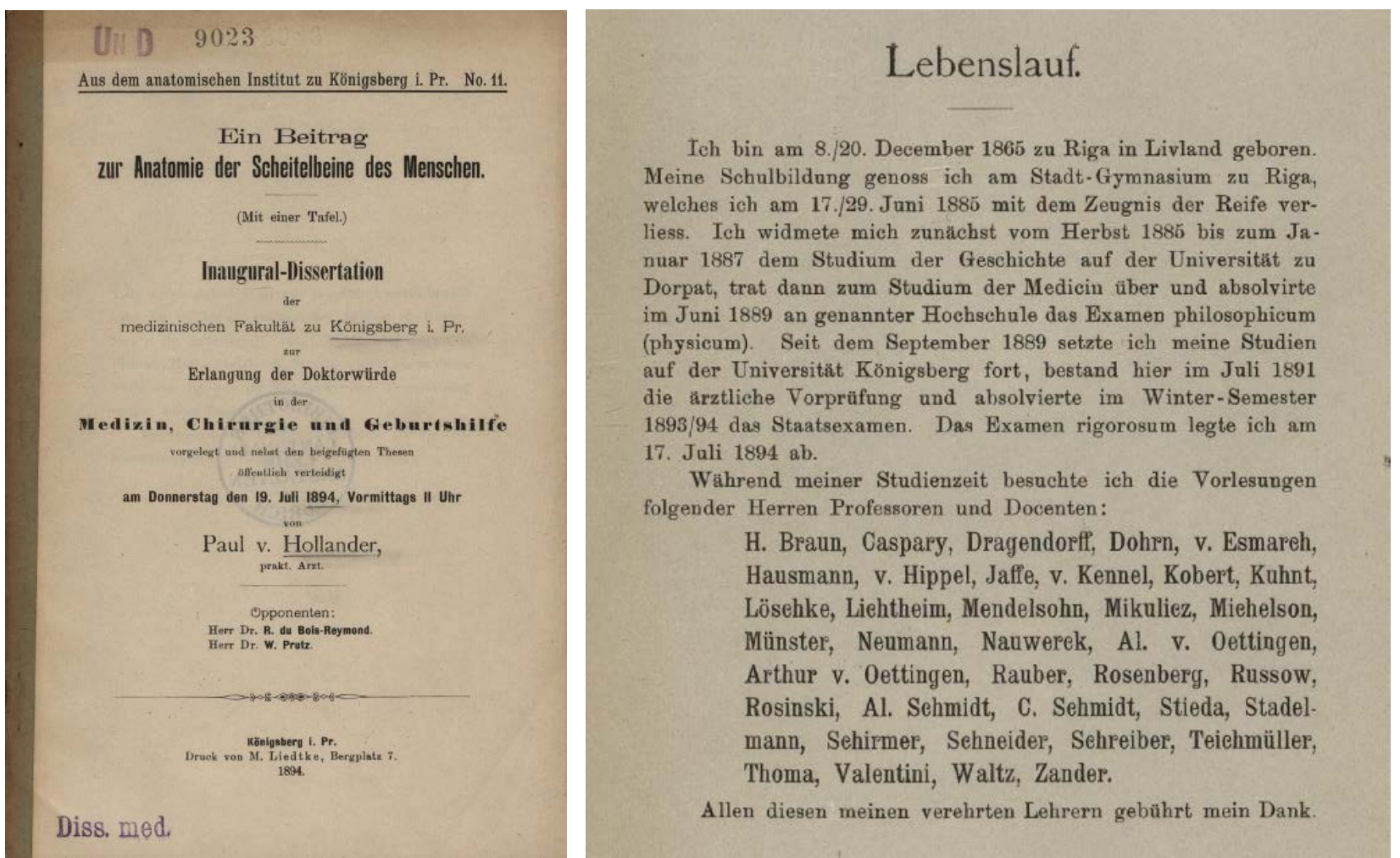

Figure 2. Paul von Hollander (1865-1937) Doctoral dissertation from 1894. He hailed from the Hollander family of Riga; his curriculum vitae (included in the dissertation) do not provide details regarding his parents. He must have been however a close relative of Eduard, the associate Mayor of Mannheim, since he lived at the same address in Mannheim as Marie Magdalene von Hollander born Carus, the mayor's mother-in-law (Tulla street 10).

Eduard von Hollander (1852-1935), son of Eduard Hollander (1820-1897) and Olga Drachenhauer (1822-1853) was married to Elisabeth (born von Hollander) (1860-1934), daughter of Dr. med. Heinrich Gustav von Hollander (1827-1888) and Marie Magdalene Carus (1831-1914). Eduard von Hollander studied law in Dorpat and was from 1898 to 1919 one of the associate mayors of Mannheim; responsible for caritative and social issues he was a member of the board of administration of the Luisenheim.

Emilie Louise Frey $(1869-1937 ; 1896)$ was the second of 15 children of Eduard and Emilie Frey-Stampfer of Basel, Switzerland (Figure 3). The father was a merchant in cotton and silk. In spring 1890 Emilie passed the university entrance exam (Zürcher kantonale Matura); with the support of her family and despite significant opposition from the University establishment she was admitted to study medicine; she was the first woman to do so at the University of Basel and to receive a Doctoral Degree. The title of her 1896 Doctoral Dissertation was: Contribution to the Etiology of Rickets (Beitrag zur Aetiologie der Rachitis). From August to October 1897 she was a volunteer physician at the Luisenheim in Mannheim. While in Mannheim she resided at M3, 5, which was the in- 
itial location of the asylum (until 1903) (Figure 3). Upon return to Basel she opened her practice at the corner of St. Alban Vorstadt and Malzgasse, where she worked until retirement 1935 . The house, built 1855 , was designed by the architect Melchior Berri (1801-1854).
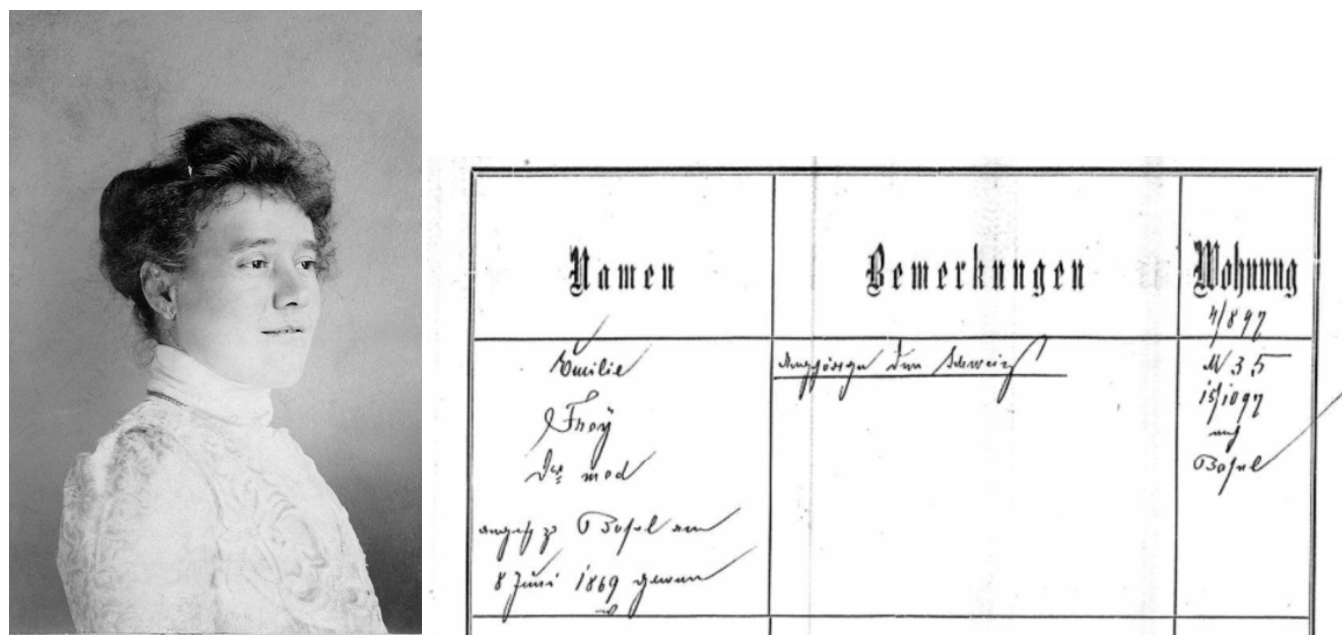

Figure 3. Emilie Louise Frey (1869-1937) of Basel (Switzerland) was from August to October 1897 a volunteer physician at the Luisenheim in Mannheim. While in Mannheim she resided at M3, 5 which was the location of the asylum until 1903. Biographical details of Dr. Frey from https://www.emilielouisefrey.ch/; photograph generously provided by Sibylle von Heydebrand and the copyright holder Dr. Bernard Zehntner, Arlesheim.

Eugen Peiser $(1875-1914 ; 1898)$ of Breslau (Silesia) was the son of Max and Lina Lasker Peiser. He graduated from Medical School in Breslau and received his Doctoral degree in 1898 with a Dissertation titled: Anatomical and clinical examinations of the lymphatics of the uterus with special consideration of its total extirpation in carcinoma uteri. He served the same year as a resident in the Luisenheim before continuing his graduate training in Leipzig, Elberfeld and Berlin. He returned 1902 to Breslau where he worked in private practice (Sonnenstrasse) until 1914 when he died of disease (Peiser, 1914). He is not to be mistaken for the surgeon Alfred Peiser (1876-1934) (University of Wuerzburg, 1901), the father of the actress Lilli Palmer.

Felix Heymann (1872-1940; 1896) of Berlin (Figure 4) received his Doctoral title from the University of Berlin 1896 with a Dissertation titled: On the effect of subcutaneous Injections of albumose and pepton (Ueber die Wirkung subkutaner Injektionen von Albumose und Pepton); herein included is also his vitae (Figure 5). His parents were the bank owner Gotthold Heymann (1833-1891) from Berlin and his Austrian-born wife Josefine von Zeissl (1849-1923). Josephine was the daughter of a distinguished dermatology Professor from Vienna, Hermann Zeissl (1817-1884), nobilitated by the Emperror Franz Joseph in 1883. Felix studied medicine in Freiburg (1890) and Berlin (1890-1896). After receiving his license (Approbation) he became 1899 a resident physician (Assistenzarzt) in Mannheim; the following year he returned to his home town and opened a private 
practice first at Kronprinzenufer, than in Berlin-Charlottenburg at Kantstrasse. Three days after World War I was declared he was drafted into the Kaiser's army. During the war he worked as a physician in a military hospital for contagious diseases. After the armistice he returned to private practice in Berlin-Charlottenburg at Berlinerstrasse 153, where the family also resided. He was married since the turn of the century to Elsa born Heymann (1876-1940) and the couple had two children Elisabeth (1905-2009) who was to become a distinguished psychoanalyst and Frederick Gotthold (1900-1982), a renowned historian. The Berlinerstrasse location was used until 1932; thereafter a quick succession of addresses can be found in the Berlin Adressbuecher, the last mention of Dr. Felix Heymann is in the 1938 edition. While Felix and his wife Elsa committed suicide in order to escape the Nazi concentration camps both children managed to flee Europe.

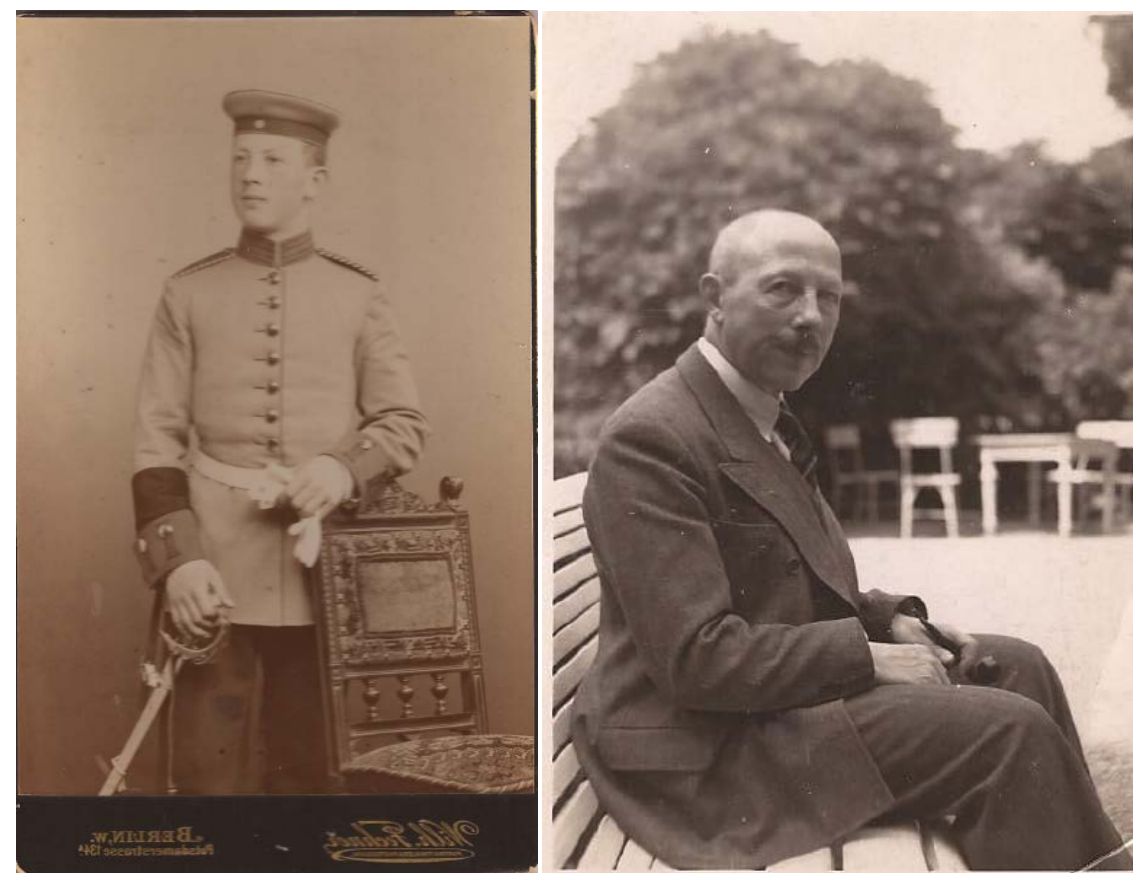

Figure 4. Felix Heymann (1872-1939) was drafted for compulsory military service after graduating from high school (Franzoesisches Gymnasium Berlin; Collège français de Berlin) in 1891; he served in the 1. Garde Dragonner Regiment (left). Dr. Heymann in the $1930 s$ (right). Biographical details and photographs of Dr. Felix Heymann of Berlin generously provided by Frank J Heymann (grandson) and Ruth Bean Heymann (granddaughter).

Karl Georg August Schumacher $\left({ }^{\star} 1879-1914 ; 1904\right)$ He was born in Weinheim (Baden), as the second son of Professor Dr. phil. Karl Schumacher $\left({ }^{\star} 1845\right)$ and his wife Frieda nee Kiefer $\left({ }^{\star} 1844\right)$. He graduated from the Gymansium zu Mannheim in 1897; autumn of same year he was admitted to the imperial military medical academy (Kaiser Wilhelm Akademie fuer das militaer-aerztliche Bildungsween) in Berlin. He served in the $2^{\text {nd }}$ Guard-Regiment (Vierte Kompagnie des zweiten Garderegiments zu Fuss) and subsequently started medical 
die Wirkung subkutaner Injektionen

von Albumose und Pepton.

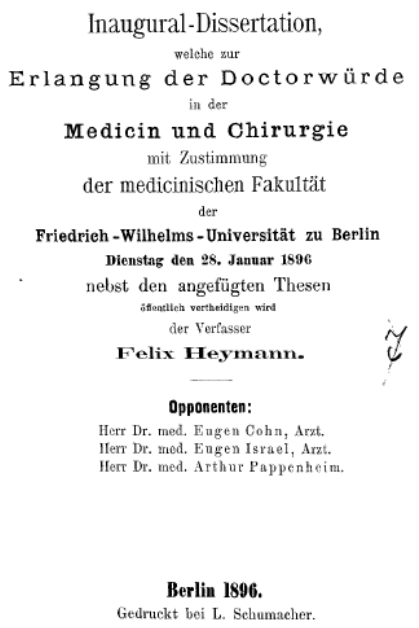

\section{Lebenslauf.}

Verfasser, Felix Heymann, Sohn des verstorbenen Banquiers Gotthold Heymann und seiner Ehefrau Josefine, geb. v. Zeissl, mosaischer Confession, wurde am 21. December 1872 zu Berlin geboren. Er besuchte daselbst das $\mathrm{kgl}$. französische Gymnasium welches er Ostern 1890 mit dem Zeugniss der Reife verliess, um Medicin zu studieren. Er besuchte im Sommersemester 1890 die Universität Freiburg, vom Oetober 1890 an die Universität Berlin. Im März 1892 bestand er die ärztliche Vorprüfung, am 19. Juli 1895 das Tentamen medicum und am 26. Juli 1895 das Examen rigorosum. Seiner Militärpflicht mit der Waffe genügte er im Sommerhalbjahr 1891 bei dem 1. Garde-Dragoner-Regiment.

Figure 5. Felix Heymann (1872-1939) received his Doctoral title from the University of Berlin 1896 with a Dissertation titled: On the effect of subcutaneous injections of albumose and pepton (Ueber die Wirkung subkutaner Injektionen von Albumose und Pepton); herein included is also his vitae.

education at the royal (koenniglichen) Friedrich-Wilhelms Universitaet Berlin where he passed March 1900 the aerztliche Vorpruefung. The clinical part of his medical training he obtained from the Friedrich-Karls Universitaet in Heidelberg (1900-1902) where he obtained the Approbation. During this time he worked as a clinical student (cand. med.) volunteer at the Luisenheim. After Approbation he joined a military unit in Mannheim and was appointed 1903 Assistenzarzt. He received his Doctoral Degree from the University of Tuebingen 1904 with a Dissertation titled: Surgery for pelvic outlet enlargement (Beckenerweiternde Operationen); supervising Professor was the Ordinarius for Obstetrics and Gynaecology Albert Doederlein (1860-1941) Subsequently he joined the Kaiserliche Schutztruppe fuer Ostafrika as Stabsarzt, was named Oberarzt and worked i.a. at the Tanga Hospital (Figure 6). Karl Schumacher was mortally wounded in the early month of the WW I (autumn 1914) while evacuating wounded soldiers after the battle of Tsavo (British East Africa).

Georg Zander (1875-1905; 1908) hailed from Konitz in Western Prussia (now Poland; Chojnice). He was one of the eight children of Moritz Zander (1830-1908) and Henriette nee Behr (1840-1884). Georg studied medicine in Wuerzburg where he received his Doctoral title 1898 with a Dissertation titled: On unpleasant coincidences during surgery of adenoidal tumors of the nose and larynx (Über unangenehme Zufälle bei der Operation adenoïder Wucherungen im Nasenrachenraume) (Figure 7). Zander worked $\approx 1900 / 1901$ as a resident (Assistenzarzt) at the Luisenheim. According to the Imperial-Physicians-Almanach (Reichs-Medicinal-Kalender) 

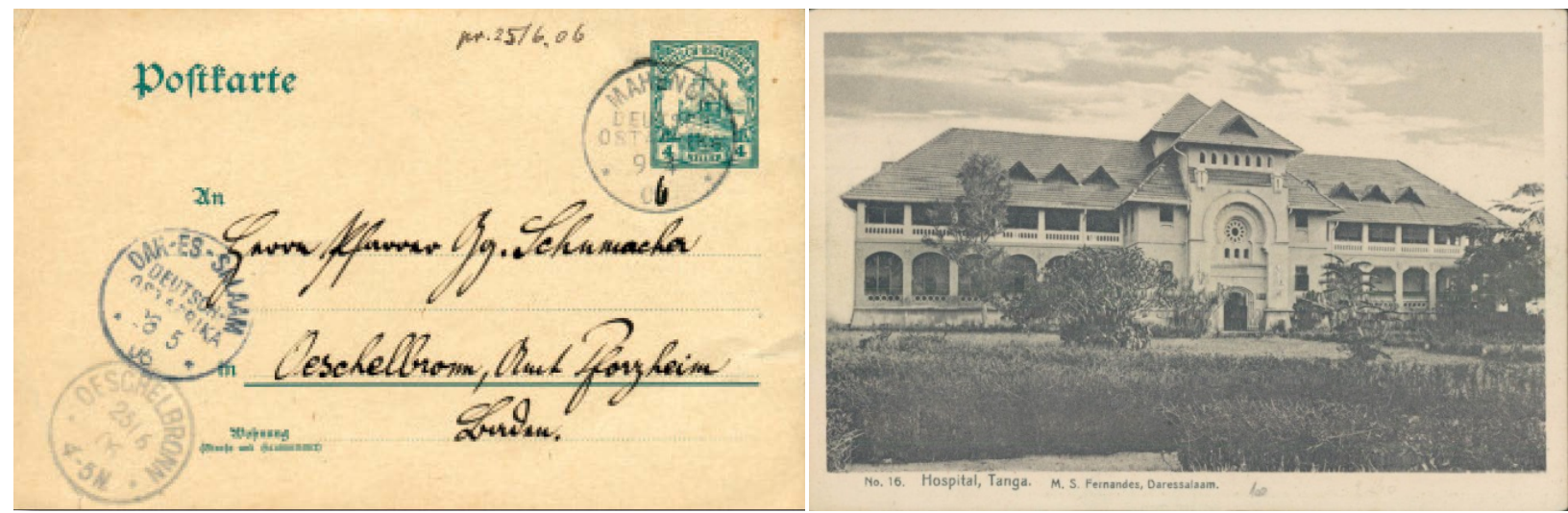

Figure 6. Karl Schumacher joined 1905 the Kaiserliche Schutztruppe fuer Ostafrika (Imperial Expeditionary Force for East Africa) as Stabsarzt (non-commissioned physician). The postcard (left) was sent by Karl Schumacher to his father in 1906 from East Africa. Schumacher worked i.a. at the Tanga Hospital (now Bombo Regional Hospital, Tanzania) shown on the right (Postcard \# 16, M.S. Fernandez, Daressalam; from the private collection of the author).
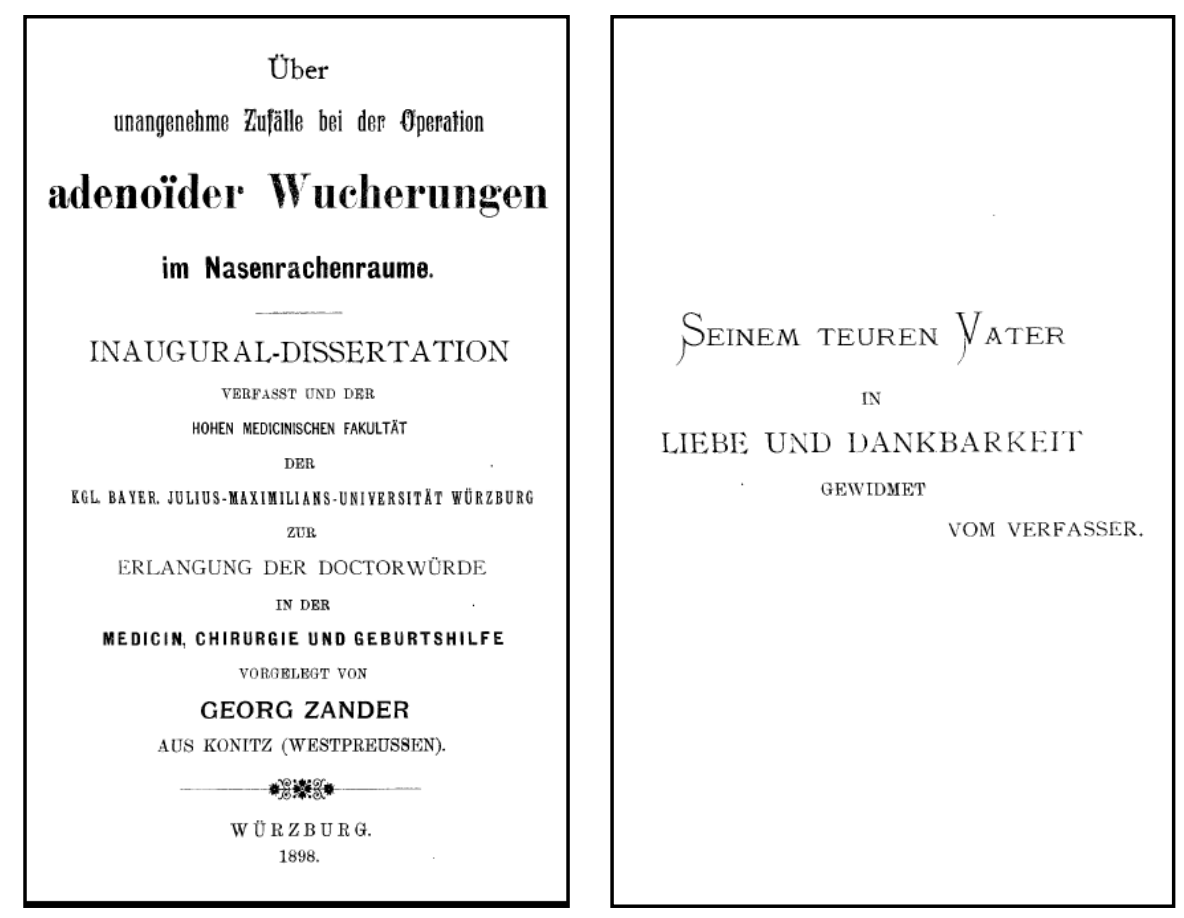

Figure 7. Georg Zander (1875-1905) studied medicine in Wuerzburg where he received his Doctoral title 1898 with a dissertation titled: On unpleasant coincidences during surgery of adenoidal tumors of the nose and larynx, the dissertation is lovingly dedicated to his father Moritz.

from 1903 he was in private practice in Berlin (Landsberger-Platz 5); subsequently he moved his practice to the posh Uhlandstrasse 160 in Berlin-Wilmersdorf. He is listed in the Berlin Adressbuch (1904 \& 1905) as Consultant for Obstetrics \& Gynecology (Spezialarzt fuer Frauenkrnakheiten und Geburtshilfe). His oldest brother Albert (1866-1940), also a Wuerzburg graduate (1890), was also in private practice in Berlin. Georg Zander passed away 1905; the death certificate is co-signed (in addition to the official) by his brother Gustav $\left({ }^{\star} 1869\right)$ ), a lawyer from Danzig (Justizrat, Rechtsanwalt und Notar). 
Georg Zander is not to be mistaken for the Swedish physician and physiotherapist G(ustaf) Zander (1835-1920) the founder of the Medico-Mechanical Zander treatment concept. The Mannheim Medico-Mechanical Zander Institute was established 1885 by Wilhelm Gabriel ( ${ }^{\star} 1857$ in Bodersweier). Gabriel was a gymanstics teacher (Turnlehrer) at the Grossherzoglichen Gymnasium in Mannheim from 1877-1889. He sold the Mannheim Institute to Drs. Martin Friedrich "Fritz" Fulda (1870-1931) and Gustav Cahen (1871-1954) and moved $\sim 1900$ to Bad Nauheim where he established a highly successful Zander Institute that operated until 1931 [after Wilhelm Gabriel death (before the outbreak of WW I) under the supervision of the orthopedic surgeon Dr. Gustav Gabriel (1890-1958), most likely Wilhelm's son]) (Figure 8).
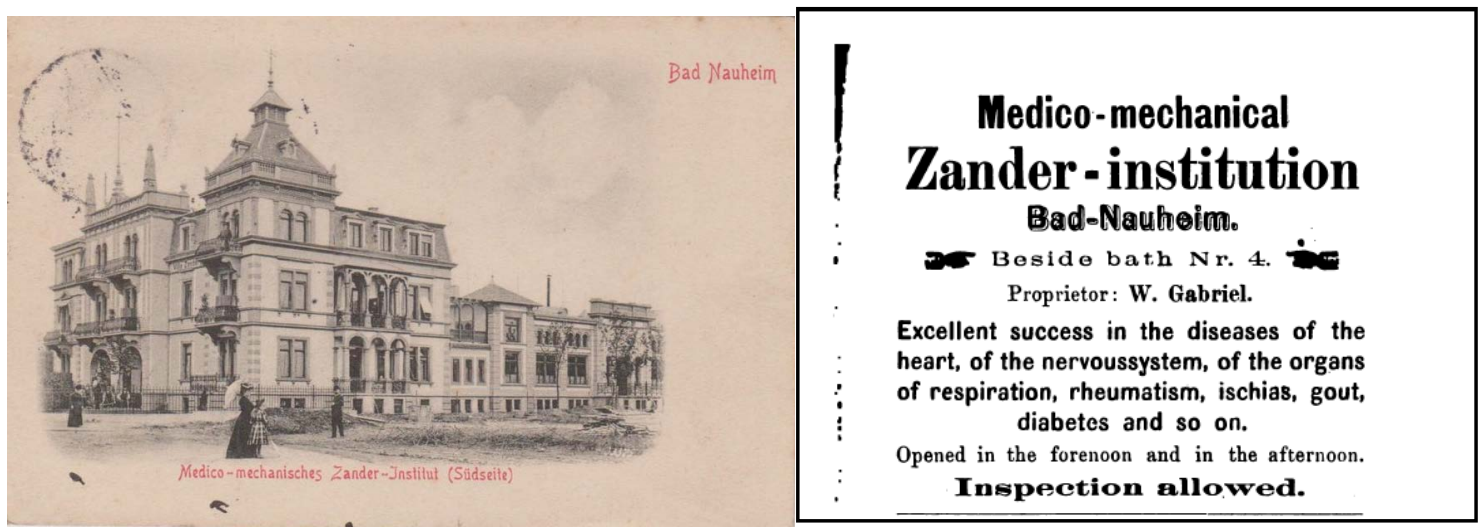

Figure 8. The Medico-Mechanical Zander Institute in Bad Nauheim established by Wilhelm Gabriel after selling the Mannheim Institute (Postcard 1906, No. 18 Edit L. Klement, Frankfurt; from the private collection of the author).

Georg Hermann van der Briele (1873 - ?; 1901) was born in Magdeburg (Saxony-Anhalt). His parents were the retired civil servant (pensionierter Versicherungsbeamte) Fritz van der Briele $\left({ }^{\star} 1842\right)$ and Anna Jacobs. Georg received his Doctoral title from the University of Leipzig 1901 with a Dissertation titled: A case of myositis ossificans traumatica (Ein Fall von myositis ossificans traumatica). As a military physician he was posted in a number of locations: 1902 Magdeburg (Sudenburg) $\rightarrow 1903$ Mannheim (Assistenzarzt Luisenheim) $\rightarrow 1908$ Blankenhain $\rightarrow$ Haina $\rightarrow$ and 1910 Rastenburg. In Rastenburg he was appointed Attending Physician (Oberarzt) at the Provincial Establishment for the Mentally Retarded (Provinzialanstalt für Schwachsinnige); he continued to work there at least until the early 1930s. In 1910 he married Camila Werneke $\left({ }^{\star} 1878\right)$ (Figure 9); they had a son Johann-Georg (1914-1941) that graduated in medicine in Rostock (1936). During the WWII the son fell on the Eastern Front.

Max Jacoby (1876-1912; 1900) was born in Mehlsack (Eastern Prussia), son of the merchant Julius Jacoby and his wife Rosette. He passed in 1895 the $A b$ iturpruefung (High School Examination) at the Kneiphöfsche Stadtgymnasium zu Königsberg, from 1895 to1899 he studied medicine in Freiburg (Albert-Ludwigs-Universität). He received his Doctoral Degree from the University 


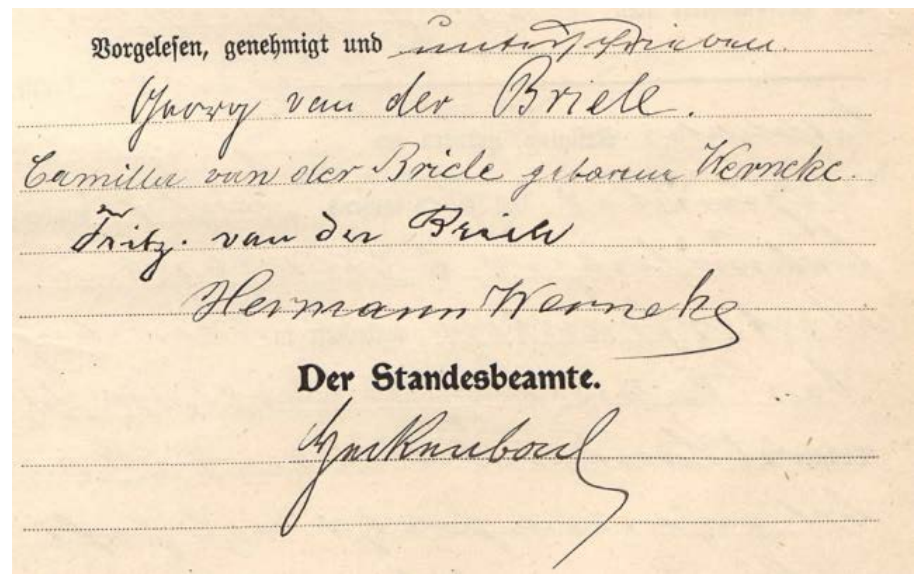

Figure 9. Signatures on the 1910 marriage certificate: Georg van der Brile, his wife Camilla born Werneke, the groom's father Fritz van der Brile and the bride's father Hermann Werneke.

of Koenigsberg in Prussia (now Kaliningrad); the title of his 1900 thesis was: On suppurative gastritis (Ueber gastritis phlegmonosa). Jacoby was the resident physician at Luisenheim around 1904/1905 (Jacoby, 1904, 1905). He married Fanny Rothschild and settled in Mannheim where he practiced obstetrics \& gynecology; the office was in O7, 11. Max passed away at early age in Mannheim-Neckarau (Waldpark am Bellenkrappen) in 1912 (he was 36).

The Max Jacoby above is often confused with other homonymous physicians contemporaneous to him.

Max Jacoby (1891 - $\approx 1936)$ (Figure 10) of Stolp (Pomerania) was the son of Justizrat Hermann Jacoby and Edith Born $\left({ }^{*} 1866\right.$ in Stolp). After passing the university entrance exam (Abitur) in 1910 he joined for 2 years a business in Berlin then changed his mind and started medical training. His medical training was interrupted by the First WW. During the war he served in the German Medical Corps (Sanitätswesen) on the Eastern front. His Iron Cross was awarded after he captured a Russian village... he walked into village and the Mayor saw he was a German officer and surrendered to him. After the war he resumed his medical studies and in 1920 he submitted his Doctoral Dissertation titled Case reports on acid damage to the esophagus (Zur Kasuistik der Veraetzungen der Speiseroehre) to the Berlin University. Same year he settled in Pollnow, Pomerania, where he opened a private practice. Max lived (first Am Markt in the house of Max Kordel (printer/publisher of the local paper), than starting 1925 in his own house on Schloss Strasse 12). Married with Emma Behr they had three children (Susanne ${ }^{\star} 1921$, Heinz ${ }^{\star} 1923$ and Otto) all of whom were educated in Switzerland at the Ecole d'Humanité in Versoix, Geneva, school founded by Paul Geheeb (1870-1961) and his wife Edith Cassirer (1885-1982). Faced with the continuous threat of arrest and deportation Max Jacoby committed suicide sometime in 1936 or early 37 . His children fled Europe and survived. Biographical details and photograph of Dr. Max Jacoby generously provided by Robert (Bob) Hammon, grandson of Dr. Jacoby. 

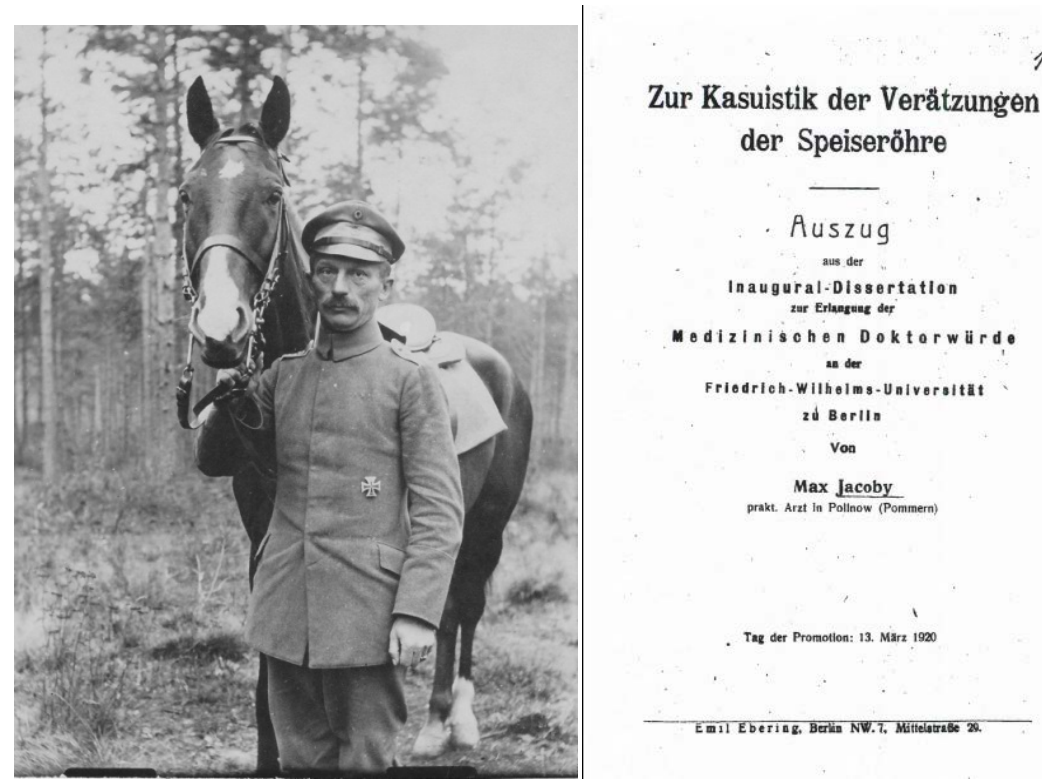

Figure 10. Biographical details and photograph of Dr. Max Jacoby (1891-1936) of Stolp (Pomerania) generously provided by Robert (Bob) Hammon, his grandson.

Max Leo Jacoby (1869-1942; 1895) of Domnau (East Prussia), the son of the merchant Leopold Jacoby and Emma Schier, received his Doctoral Degree from the University of Koenigsberg; the title of his 1895 thesis was: Kritik einiger neuerer Behandlungsmethoden der Ozaena und Darstellung eines neuen, vereinfachten Verfahrens. He practiced medicine in Berlin-Neukoelln as a General Practitioner (praktischer Arzt) for over thirty years (1898-1931); the consultory was in the Hermannstrasse 53. After the first WW war he was appointed Sanitaethsrat (Medical Counsellor). He married 1924 and had a son. In 1932 he moved to Berlin-Friedenau and then 1935 to Schöneberg in the Landshuterstrasse from where he was deported September 1942 to the Theresienstadt concentration camp.

Max Jacoby $\left({ }^{\star} 1863\right.$ - ?; 1888) of Darkehemen (East Prussia) was the son of the merchant Philipp Jacoby. The family moved from Darkehemen to Angerburg when he was a baby. After receiving his Zeugniss der Reife from the Gymnasium zu Lyck he studied medicine in Koenigsberg where he received his Doctoral degree; the title of his 1888 thesis was: Fünfzehn Fälle von Laparotomie bei festen Tumoren aus der gynäkologischen Klinik zu Königsberg in den Jahren 1883-6.

Max Jacoby (1888-1971; 1912) of Nauen (Osthavelland) was the son of Albert Jacoby and Berta Meyerstein. He studied medicine in Munich and Berlin and received his Doctoral Degree from the University of Berlin; the title of his 1912 thesis was: Ueber Dekompressionstrepanationen und Duraplastik. After WW I he practiced medicine in Berlin as urologist (Spezialarzt fuer Nieren und Blasenleiden) for some fifteen years (1918-1933); the consultory was in the Friedrichstrasse 133. He emigrated 1938 via Switzerland to the United States where he practiced urology at Mount Sinai Hospital in New York.

Albert Eckert (1877-1915; 1902) from Fuerth (Bavaria), son of Max Eckert (of 
independent means), was a military physician. He studied in Munich and Erlangen and received 1902 his Doctoral Degree from the University of Erlangen with a thesis titled: Examination of various chesses regarding bacterial contamination with swine erysipelas (Untersuchung verschiedener Kaesesorten auf Schweinerotlaufbakterien). In 1906 he was the resident at Luisenheim where he performed many morphine-scopolamine anesthetic procedures on parturients (expanded and reported by his successor Preller). Eckert published a review of the history and activities of the Luisenheim (Eckert, 1906). He was married to Elisa born Amann. He passed away in his residence in Nuerenberg, July 1915.

Walther Bender (1883-1942; 1907) from Mannheim (Baden) was the son of Augustin Bender (1853-1918) and Karola born Wahl (1861-1930). The Bender's were a successful industrialist family from Mannheim; Heinrich Adam, the founder of the dynasty (Walther's grandfather), having established the Korkstopfenfabrik (Corkfactory) (Figure 11). Walther studied medicine in Munich (1904) and Freiburg and received 1907 his Doctoral Degree from the University of Freiburg with a thesis titled: Melaena neonatorum. Around 1913 he is Assistenzarzt at the Luisenheim (Gawliczek, 1978). In 1921 he married Ilse Hanser $\left({ }^{*} 1895\right)$ the daughter of Dr. Alfred Hanser and Paula Bensinger. Walther Bender practiced medicine in Mannheim $(\mathrm{O} 7,16)$ and then in Heidelberg (Friedrich-Ebert-Anlage 61). He served as a military physician (Stabsarzt). The August-Bender-Villa in Mannheim Erzbergerstrasse 10 was designed by the architect Albert Speer, the father of the Reichsministers and architect Albert Speer; the villa was transformed later into the Oststadt-Klinik an orthopedic institution specialized in hand surgery. (Both as a student and anesthesia resident the author [GP] worked in the Klinik).

Rudolf Katz (1876 - ?1938; 1898 Wuerzburg) from Kattowitz (Upper Silesia) was the son of Julius Katz and Flora Fiedler. The father was a wealthy coal trader. The children, Rudolf and his younger brother Fritz (1879-1916) grew up on the Rittergut Goldschmieden in Deutsch Lissa (Figure 12). A Rittergut is a property that (previously) belonged to a knight. Rudolf and Fritz both attended

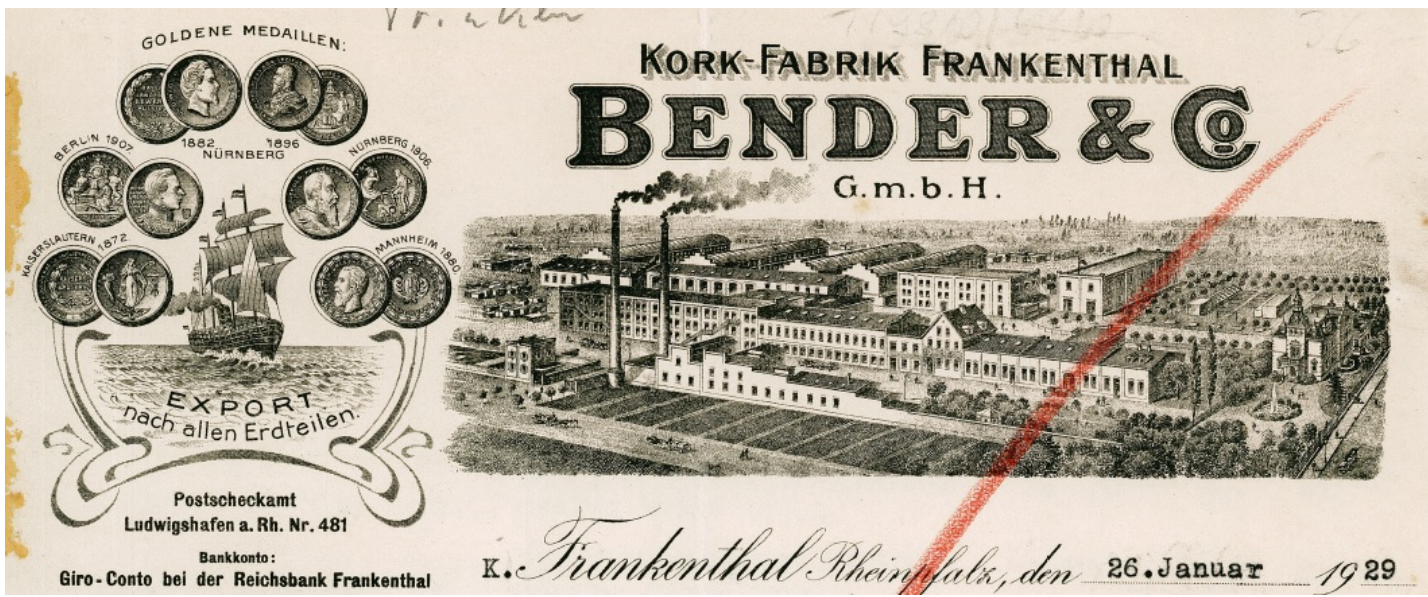

Figure 11. Stationery of the Bender Cork factory (from the private collection of the author). 

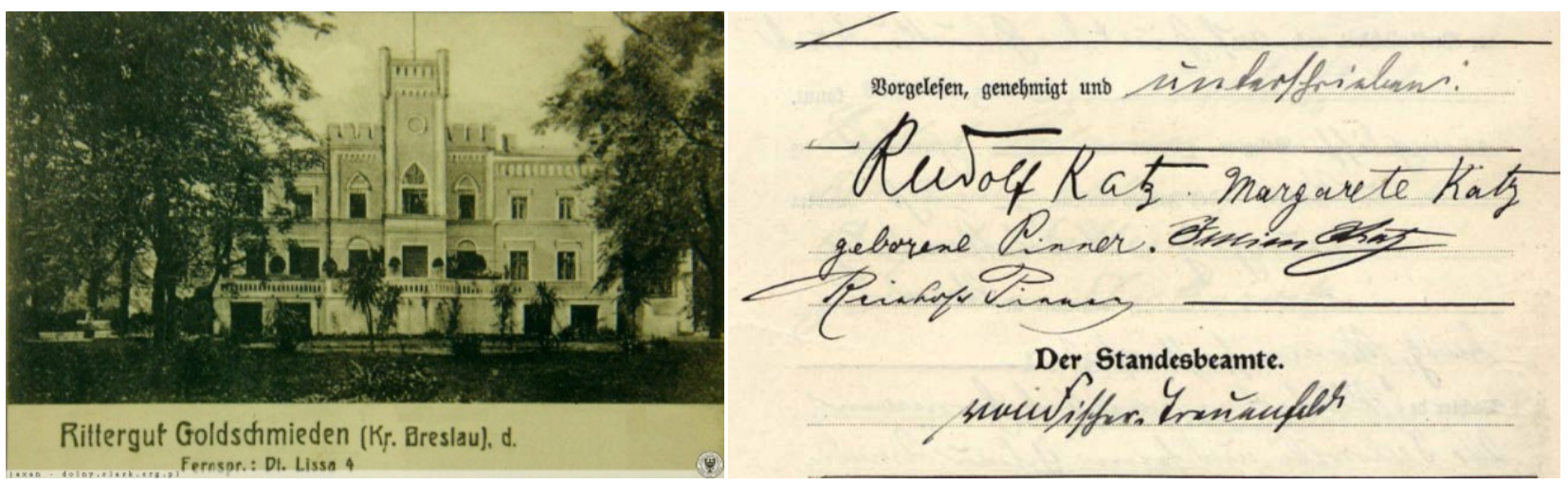

Figure 12. Rudolf Katz (1876 - ?1938) and his younger brother Fritz (1879-1916) grew up on the Rittergut Goldschmieden in Deutsch Lissa. Right: Signatures on the 1912 marriage certificate.

the prestigious Gymnasium St. Maria Maggdalena zu Breslau. Rudolf went on to study medicine and received 1898 his Doctoral Degree from the University of Wuerzburg with a thesis titled: Ueber die Behandlung der Kompressionslaehmung des Rueckenmarks mit Extension. Subsequently $(\approx 1903)$ he worked as a resident in Berlin (Dr. Abels Privatfrauenklinik) and then $(\approx 1905)$ in Mannheim in the Luisenheim. In 1906 he returned to Berlin and worked as Frauenarzt in his private practice for over thirty years. His private residence was in the Motzstrasse (Willmersdorf), later in the Bergstrasse (Neukoelln). He married in 1912 Margarete Pinner, the daughter of Reinhold Pinner, owner of a large banking and cereal business. The last mention of Dr. Rudolf Katz in the Berliner Adressbuch is in year 1938.

Karl Preller $\left({ }^{*} 1877-?\right)$ from Trennfurt (Miltenberg in Unterfranken) received his Doctoral degree for a dissertation presented 1902 to the University of Jena titled: On Keratokonus with special attention to the pulsating one (Ueber Keratoconus, besonders den pulsierenden). He was the resident physician at Luisenheim succeeding Alfred Eckert. Preller's main interest was in surgical and anesthetic procedures to be used during delivery, especially the use of opioids and anticholinergics (Preller, 1907a, 1907b). Upon Mermann's death in 1908 Preller became the Director of the institution. He was also the author of Mermann's obituary (Preller, 1908). In Mannheim Preller lived first in L3, 3 than in the $1920 \mathrm{~s}$ he moved into the posh Villa Eckhard in L11, 14. The villa was built for and named after Carl Eckhard (1822-1910) - a successful politician and businessman that spent the later part of his life in Mannheim.

\section{Conclusion}

The Luisenheim was a most successful institution not only due to the foresight of his director Dr. Mermann, but also due to the contribution of many other people involved, such as the very supportive city's first mayor Oberbürgermeister Otto Beck and his associate mayor Eduard von Hollander, as well as many midwifes and resident physicians. The physicians involved in the daily operation of the Luisenheim are representative of the socially engaged physicians at the 
turn of the century.

\section{Conflicts of Interest}

The authors declare no conflicts of interest regarding the publication of this paper.

\section{References}

Brennecke, E. (1899). Sonderkrankenanstalten und Fuersorge fuer Frauen (J. P. Liebe E, Meyer G Ed.). Berlin: August Hirschwald Verlag.

Eckert, A. (1906). Das Wöchnerinnenasyl "Luisenheim" in Mannheim. Deutsche Vierteljahrsschrift für öffentliche Gesundheitspflege, 38, 295-303.

Frey, E. (1897). Zur Kasuistik des Kaiserschnittes mit Kastration bei Osteomalakie. Zentralblatt fur Gynaekologie, 46, 1361-1365.

Gawliczek, O. H. (1978). Aerzte in Mannheim im Jahre 1913. Bezirksaerztekhammer Nordbaden.

Heucklenbroich, A. (1898). Das Woechnerinnen-Asyl. In Düsseldorf im Jahre 1898 (pp. 194-195). Festschrift Verlag August Bagel.

Heyman, F. (1899). Über Methoden und Indicationen der künstlichen Unterbrechung der Schwangerschaft. Archiv für Gynaekologie, 59, 404-515.

https://doi.org/10.1007/BF01833527

Jacoby, M. (1904). Über die künstliche Unterbrechung der Schwangerschaft durch die Bougiemethode. Archiv fuer Gynaekologie, 74, 261-291. https://doi.org/10.1007/BF01733255

Jacoby, M. (1905). Ueber den Riesenwuchs von Neugeborenen. Archiv für Gynäkologie, 74, 536-566. https://doi.org/10.1007/BF01681778

Katz, R. (1905). Zur Kasuistik der submukösen Myome. Monatsschrift für Geburtshilfe und Gynäkologie, 21, 222-228. https://doi.org/10.1159/000285469

Mermann, A. (1880). Klonischer Zwerchfellkrampf im Foetalleben. Zentralblatt fuer Gynäkologie, 4, 377-379.

Mermann, A. (1883). Aphorismen über das Hebammenwesen. Centralblatt fuer Gynäkologie, 45, 713-719.

Mermann, A. (1884). Ueber Vaginalinjectionen bei normaler Geburt und normalem Wochenbett; ein Beitrag zur Aetiologie und Prophylaxe des Puerperalfiebers. Archiv fuer Gynaekologie (Berlin), 23, 146-155. https://doi.org/10.1007/BF01968431

Mermann, A. (1887). Über eigentümliche rhythmische Fetalbewegungen. Zentralblatt fuer Gynäkologie, 11, 622-624.

Mermann, A. (1903). Festschrift zur Eröffnung des neuen Wöchnerinnenasyls Luisenheim in Mannheim. Mannheim: Buchdruckerei, GmbH.

Metz, V. J. (1838). Das Mariannen-Institut zu Aachen: eine Entbindungs-Anstalt für arme Wöchnerinnen. Aachen Verlag I U Mayer.

Miller, C. C., \& Petroianu, G. A. (2018). Alphons Mermann (1852-1908): Hiccups, Hygiene and Hebammen. Journal of Medical Biography, 26, 29-33.

https://doi.org/10.1177/0967772015596277

Peiser, E. (1898). Verblutungstod der Frucht unter der Geburt infolge Ruptur einer Umbilicalarterie bei Insertio velamentosa. Monatsschrift für Geburtshilfe und Gynäkologie, 8, 619-624.

Peiser, E. (1899a). Klinische Beiträge zur Frage der Entstehung und Verhütung der fie- 
berhaften Wochenbetterkrankungen. Archiv für Gynäkologie, 58, 248-293.

https://doi.org/10.1007/BF01981128

Peiser, E. (1899b). Beitrag zur Pathologie der Placenta. Monatsschrift für Geburtshilfe und Gynäkologie, 10, 613-626. https://doi.org/10.1159/000281045

Peiser, E. (1914). Jahresbericht der Schlesischen Gesellschaft fuer vaterlaendische Kultur.

Preller, K. (1907a). 13 Faelle von Pubiotomie. Monatsschrift fuer Geburtshuelfe und Gynaekologie, 25, 623-650.

Preller, K. (1907b). Zur Anwendung von Skopolamin-Morphium in der Geburtshilfe. Muenchener Medizinische Wochnschrift, 4, 161-165.

Preller, K. (1908). Medizinalrat Dr. Alfons Mermann. Monatsschrift fuer Geburtshuelfe und Gynaekologie, 28, 214-215.

Schmitz-Cliever, E. (1966). Die Gründung des ersten Wöchnerinnenasyls in Deutschland (1830). Sudhoffs Archiv, 50, 136-156.

Schumacher, K. (1901). Zur Kasuistik der puerperalen Uterusinversionen. Zentralblatt für Gynäkologie, 25, 640-641.

Van Der Briele, G. (1903). Sectio caesarea und Ovariotomie wegen eingekeilten Ovarialtumors. Zentralblatt fur Gynaekologie, 27, 133-136.

Zander, G. (1901). Ein Fall von anus praeternaturalis vestibularis. Zentralblatt fur Gynaekologie, 25, 1241-1243.

Zander, G. (1902). Ein Fall von Embryotomie bei lebendem Kinde. Zentralblatt fur Gynaekologie, 26, 364-368. 